Council on Education in Washington DC. Current students might leave, and prospective ones could decide against applying to US graduate schools. "The US could wind up with a shrinking pool of $\mathrm{PhD}$ students, leaving research labs without qualified graduate students to help PIs conduct research," says Jennifer Zeitzer, director of legislative relations at the Federation of American Societies for Experimental Biology in Bethesda, Maryland.

The tuition tax could also stifle socioeconomic diversity in science. "Those who can afford to pay more taxes can go to graduate school. Those who can't, won't," says Andrew Campbell, dean of the graduate school at Brown University in Providence, Rhode Island.

Income-tax calculations depend on several factors, such as marital and family status, as well as tuition costs, which differ by university. But some students have taken a stab at working through the numbers.

For students earning around \$37,000 annually at Yale University in New Haven, Connecticut, their taxable income could double, estimates Yale immunobiology PhD student Michael Parker.

At the University of California, Berkeley, physics $\mathrm{PhD}$ student Vetri Velan estimates that Berkeley students would pay $30-60 \%$ more in taxes; those at the Massachusetts Institute of Technology in Cambridge could pay $240 \%$ more.

Most universities have stayed quiet on how they will cope if the tuition tax becomes law.
Wary of stoking premature hope or concern, Campbell, too, would not comment on Brown University's plans. But he did note that small, public institutions - including ones that historically educated black students - may be least able to absorb costs for students. "This tax could really threaten the existence of graduate education at minority-serving institutions," Campbell says.

However, the Senate has shown little appetite for the tax, says Jessica Sebeok, the AAU's associate vice-president and counsel for policy, and there are signs of renewed debate in the House. "They've gotten enough concerned contact from their constituents to possibly rethink it," she says. "We are cautiously optimistic." -

\title{
Geoscientist faces criminal charges over glacier survey
}

\section{Ricardo Villalba stands accused of shaping a study to benefit the mining industry.}

\section{BY JEFF TOLLEFSON \& EMILIANO RODRÍGUEZ MEGA}

$\mathrm{A}$ prominent geoscientist in Argentina is facing criminal charges over accusations that he manipulated a government survey of glaciers at the behest of mining interests.

On 27 November, a federal judge in Buenos Aires charged Ricardo Villalba, former director of the Argentinian Institute of Snow, Ice and Environmental Research (IANIGLA) in Mendoza, with abusing his authority and violating his duty as a civil servant. Villalba appealed against his indictment on 4 December - but if he loses, the case will go to trial. In the meantime, the court has ordered him to stay in the country, and has authorized the seizure of his assets up to 5 million pesos (US\$289,000).

The case hinges on the definition of a glacier as viewed from space. When Villalba began the government survey in 2011, he determined that it would include glaciers of 1 hectare or larger - following international norms for satellite analyses. But environmental activists in Argentina's San Juan province argue that he excluded some smaller glaciers to prevent tough regulation of adjacent mines operated by the Barrick Gold Corporation of Toronto, Canada. Villalba's scientific colleagues in Argentina and abroad say the charges against him are baseless and political.

"It's surreal and kind of ridiculous," says Bruce Raup, a glaciologist at the US National Snow and Ice Data Center in Boulder, Colorado, who co-authored a letter of support for Villalba. Raup maintains an international glacier database that includes information from the ongoing Argentinian survey. $\mathrm{He}$ says that many scientists set a minimum glacier size of 1 hectare to reduce the risk of incorrectly counting ephemeral snow and ice.

Villalba rejects the idea that he or his colleagues at IANIGLA failed to carry out their duties properly. "There is no other institution in Argentina that has done more for the knowledge, care and protection of glaciers than IANIGLA," he says. The allegation that the glacier surveys were designed to promote mining interests "is totally wrong", he says, and a blow to science in Argentina generally.

Other scientists have rushed to his defence. Villalba's co-workers at the National Scientific and Technical Research Council (CONICET) in Mendoza protested on his behalf as he entered his appeal on 4 December. And scientists in other countries who have worked with Villalba are collecting signatures on a letter defending him and his glacier survey. Many of these
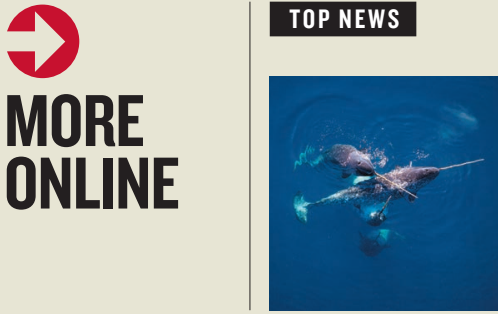

Narwhals mixed-up response to fear could kill them go.nature. $\mathrm{com} / 2 \mathrm{be} 056 \mathrm{c}$

\section{MORE NEWS}

- Trump tells NASA to return to the Moon go.nature.com/2yhm3tb

- Brexit-breakthrough raises hope - and questions http://go.nature. com/2kpcl7n

- Misconduct found in Swedish fish research go.nature.com/21110ey

\section{NATURE PODCAST}

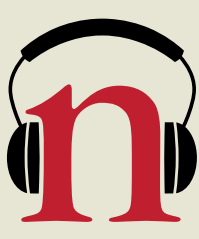

Electric-eel inspired batteries; virus-inspired protein shells; and modelling magma viscosity nature.com/ nature/podcast 


\section{NEWS INFOCUS}

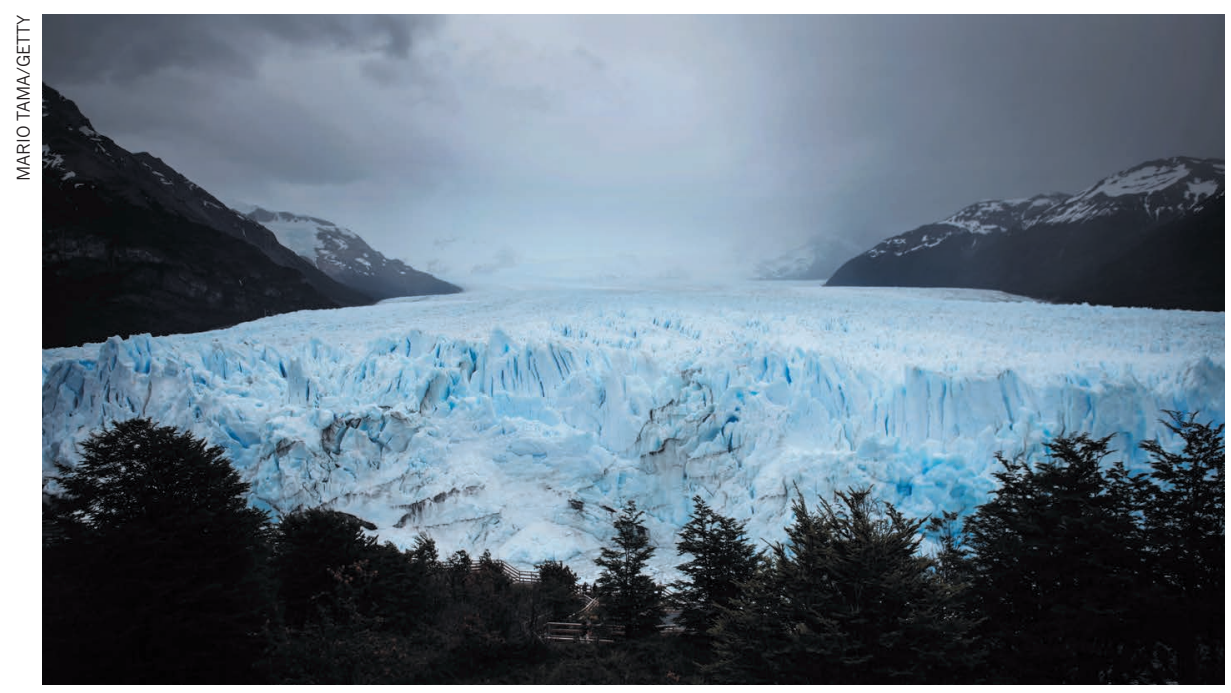

Glaciers provide the bulk of Argentina's drinking water.

- researchers see parallels between Villalba's case and that of six seismologists who were prosecuted after an earthquake in L'Aquila, Italy, in 2009; those scientists were found guilty of manslaughter for misleading the public about the seismic risk, although their convictions were later overturned.

The charges against Villalba stem from a lawsuit by environmental activists in San José de Jáchal, a community in the later coordinated.

The environmental activists argue that Villalba and his colleagues should have documented all glaciers, no matter their size including ice in the vicinity of Barrick Gold's Veladero gold mine, near San José de Jáchal. "The law did not distinguish glaciers by surface or size," says Diego Seguí, a lawyer who is representing the activist group, the Asamblea Jáchal No Se Toca.

If the ice near the mine had been mapped, the activists say, the law would have required the scientists to audit the Barrick facility's impact on glacial resources. They claim that this would have halted activities there, thus preventing three cyanide spills that have taken place at the mine over the past two years.

Villalba and his allies reject that idea. They say that as a science agency, IANIGLA is not responsible for enforcing environmental rules. Instead, they argue, the responsibility of maintaining environmental safety at the Veladero mine is the duty of Barrick and of Argentina's environmental regulators.

"Clearly there is no relationship between the actual mapping and the spill of cyanide," says Tom Veblen, a geographer at the University of Colorado Boulder who was Villalba's graduate adviser. "Ricardo is being used as a scapegoat, without a doubt." 